\title{
Digital Borders in the EUROPEAN UNION
}

\section{Introduction}

The digital society has not only revolutionized citizens' personal relationships by shortening distances and connecting individuals located thousands of kilometres away in real time. Technological advances have also influenced the world's political and economic relations, necessitating a change in the rules that have served to regulate the relations between territorial units in a global space.

While at other moments in history political and military power dominated the world stage, nowadays the increase in productivity, technological innovation, and the sustainability of development and the revitalization of economies has taken on an important role which demands the integration of both regional and international markets.

The globalization of the markets has removed economic borders that nevertheless must be legally rebuilt to respect the protection nations require, since it has not been possible to create a uniform regulatory framework, which obliges territorial limits to be established. Thus, for example, Canadian law may be different from French law, with legal responsibilities existing that act to protect the rights of individuals and entities. This is the case of copyright, which operates territorially in such a way that the protected work in one country has no protection in another. ${ }^{1}$

Therefore, despite the fact that digital technologies have eliminated borders and while the world operates on the basis of national laws, it will

* Prof. of International Law, Abat Oliba CEU University, e-mail: cparra@uao.es; https://orcid.org/0000-0002-5954-5553. 
be necessary to replicate territorial limits on the Internet in order to comply with the legal requirements of each nation. ${ }^{2}$

To respond to this economic framework, we must analyse in greater depth the mechanisms developed to make the opening of markets compatible with the protection of economic operators that act at the national level. To do this, we will analyse the impact of geo-economics and geo-blocking as mechanisms that respond to the challenges posed by the clash of interests in the new global economic framework. ${ }^{3}$

For this, it will be necessary to establish a working hypothesis that determines the influence of digitization in the geoeconomic framework and then analyse its effect in different economic spaces. The question is whether states should support this kind of legislation that segments the market or whether they should instead seek spaces for regulatory harmonization to avoid the compartmentalization of international markets. Finally, we will analyse the legislation of the European Union to know how it applied global principles to save the single market while maintaining the territorial limits that the Member States oblige by blocking digital borders.

\section{The new geo-economic order}

In the global scenario of a digitalized world in which new technologies operate, so-called geo-economics - a complex concept in which the survival of the nation and its territorial integrity is conditioned more by social cohesion and the capacity to maintain its economic competition than by external factors - acquires special importance. ${ }^{4}$ In other words, geo-economics is a part of geopolitics, which allows us to analyse the international

1 P.A. De Miguel Asensio, Contratos Internacionales sobre Propiedad Industrial, Madrit 2000, p. 38. T. Marketa, The Multiplicity of Copyright Laws on the Internet, Fordham Intellectual Property, Media \& Entertainment Law Journal 2015, vol. 25, no. 2, esp. p. 340.

2 P.A. De Miguel Asensio, Contratos Internacionales..., p. 55, J.L. Goldsmith, T. Wu, Who Controls the Internet? Illusions of A Borderless World, New York 2006, p. 152.

3 R. Millán García, Geolocalización: legislación y consecuencias de su uso, Actualidad Administrativa 2019, no. 4 , p. 4.

4 Geo-economics differs from geopolitics in that the latter focuses on the impact on the policy of geographical and security aspects, while geo-economics focuses on the impact of the economic activities of nations from a territorial perspective. 
system and the behaviour of the actors (public and private) from the perspective of economic interests. ${ }^{5}$

In this regard, Edward Luttwak ${ }^{6}$ and Pascal Lorot ${ }^{7}$, considered the pioneers of this concept, define it from a geopolitical perspective as a discipline focused on the analysis of national strategies whose purpose is not to control the territory but to gain technological and commercial supremacy. In the words of Luttwak, "geo-economics' is the best term I can think of to describe the mixture of the logic of conflict and the methods of trade; the main "battlefield" is economic rather than military, sanctions replace armed attacks and competition between trade regimes replaces military alliances. Today, Kenichi Ohmae ${ }^{8}$ and Matthew Sparke ${ }^{9}$ have taken it a step further, considering the effects of technologies on nation states by providing solutions in which they analyse the coexistence of "cross-border regionalism" together with the effects of the "transnational state that contains transnational governance imperatives in the context of free trade". ${ }^{10}$

These authors argue that the nation state has lost prominence, with companies and consumers being the true drivers that are dictating the course of the economic and political life of countries. From this point of view we have to look for new formulas that combine capital investment, global industry and new technologies, to which we must add the power of the consumer, as elements to be taken into account in order to map out the economic framework of the $21^{\text {st }}$ century. It concerns, therefore, the removal of nation-state borders, converting companies and consumers into players in the world economy.

However, reality tells us that conflicting interests exist between consumers who advocate for a free economic space and companies that must protect their economic interests. Thus, for example, audiovisual media

5 The main actor in geopolitics is the nation state, while in the geo-economic perspective shares the stage with the private actors with whom the protagonism is disputed.

6 E. Luttwak, From Geopolitics to Geoeconomics, The National Interest 1990, no. 20, pp. 19-20.

7 Introduction à la Géoéconomie, Ed. P. Lorot, Paris 1999, pp. 28-20.

8 K. Ohmae, El fin del Estado-Nación. El ascenso de las Economías Regionales, Santiago de Chile 1997, p. 54.

9 M. Sparke, From geopolitics to geoeconomics: Transnational state effects in the borderlands, Geopolitics 1998, vol. 3, no. 2, pp. 85-86.

10 Ibidem, pp. 72-75. 
that broadcast sports events generate substantial revenues by dividing the market with exclusive licences that charge consumers in each territory, and as a result are not interested in offering these services globally.

In this context we have to seek mechanisms that allow the universalism of the global market and the segmentation of the territorial market to coexist, respecting the rights of the actors involved in the economic space. For this, the protection consumers demand of the online world together with the transparency and credibility necessary to create a climate of trust in commercial operators must be taken into account on the one hand and, on the other, the regulatory protection demanded by companies of nations to avoid conduct contrary to compliance with the rules of competition in sales and services provided online by operators who do not respect the self-regulation of the global market.

In short, in a geoeconomic scenario, the states and citizens are in the background, taking the role of companies and consumers, to which must be added a digital space in which the borders are blurred and for which new solutions must be sought. For this, geoblocking is a tool that is being used to curb the digital impact on the geoeconomy, seeking again public and private collaboration to protect economic interests that states want to defend. Next, we will analyse what impact geoblocking has on different territorial spaces.

\section{The geo-blocking control mechanism}

Faced with this geo-economic scenario, responses have emerged from nations through tools that allow the preservation of the interests of companies that act globally while minimizing the impact on the rights of consumers, who qualify these barriers as an attack on the digital single market.

One of these mechanisms is geo-blocking, understood as the action of blocking access to services and/or the provision of products based on the geographical origin of the user/client, either by redirecting users to local websites or simply by restricting access to a company's product catalogue and/or conditioning the sale price. Geo-blocking therefore involves a restriction in access to content on the Internet based on the physical location of the user in a territory (geolocation) either through the identification 
of the Internet connection (IPv4 Protocol vs IPv6), the identification of the device (for example, the EFF footprint) or the linking of particular acts on the Internet to a specific user (based on IP addresses vs a combination of information that includes, for example, Wi-Fi and GPS signals). This automatically leads to market segmentation and therefore a serious attack on the liberalization of trade and services offered globally.

Its limiting nature has been criticized, since the territorial control that it implies is by nature contrary to the liberalized market that the Internet advocates. At the same time, increasing numbers of users are trying to circumvent its application and thus the costs of creating mechanisms that ensure regulatory compliance by nations are higher. Therefore, countries try to minimize restrictive rules they consider useless or easy for users to get around. One example is the dispute brought before the New Zealand courts regarding GlobalMode Bypass, a product sold as a "geographical unlocking solution" for ISPs, which was resolved in June 2015. Although no guidance was issued on the limits of geo-blocking in New Zealand, the practical result was the promise of the tool's withdrawal to avoid such measures in the New Zealand market. ${ }^{11}$

However, geo-blocking is defended by those who believe that its existence encourages economic operators to diversify their range on the Internet in the certainty that their rights are protected. In other words, geo-blocking allows content to be available where it is legal through a licensing system with territorial scope. For example, online gambling and copyright are sensitive areas of regulation that need this type of territorial protection in order to operate.

Ultimately, the only way for geo-blocking to be accepted by economic operators is to justify its usefulness, demonstrating that at the present time it is necessary to control the market given the existence of territorial regulations that force certain sales and services to be limited. ${ }^{12}$ Next, we set out the criteria that allow geo-blocking to be accepted and therefore be accepted within territorial units.

11 J. Kirk, Geoblocking Question Unresolved After New Zealand Lawsuit Ends, PC World, 23 June 2015.

12 M. Trimble, Geoblocking, Technical Standards and the Law, Scholarly Works Paper 2016, no. 947, p. 58. 


\subsection{Territorial regulations to control geo-blocking}

Geo-blocking therefore emerges as a tool that allows the legalization of the segmentation of the digitalized economic space, justifying its action through regulations that block free access to certain activities based on reasonable criteria. Therefore, for geo-blocking to be accepted by economic operators, the following conditions must be met ${ }^{13}$ :

a) That it be accepted as a regulation and compliance tool with the mandatory norms established by countries. For example, no one would question banning the purchase of weapons by someone living in Spain through the website of a company located in the United States, a country where the sale of weapons is legal.

Although attempts have been made to comply with these conditions, there is widespread criticism of the application of geo-blocking because it is believed that this mechanism is used to personalize the location of services and advertising using a specific language or differentiating price policy in a discriminatory way depending on the space geographic to which the business owner is directed.

b) That it be considered as a valid means to comply with laws that create rights and responsibilities with territorial limits. For example, regulators of online gambling in some jurisdictions require their licensees to use geo-blocking tools to allow users to access content only within jurisdictions where online gambling is legal. In this regard, German courts pronounced in favour of geo-blocking as a sufficiently reliable tool to comply with the territorial limitations established by law for online gambling. ${ }^{14}$ As these judicial decisions suggest, geo-blocking can be recognized by courts as the indispensable compliance tool to respect the territorial norms imposed by countries. This jurisprudential interpretation is important since it can be considered a standard practice cited by players operating in the digital market to justify the territorial restriction on access to Internet content.

${ }^{13}$ M. Trimble, The Future of Cybertravel: Legal Implications of the Evasion of Geolocation, Fordham Intellectual Property, Media \& Entertainment Law Journal 2012, vol. 22, no. 3, p. 578.

14 Oberlandesgericht Münster, 13 B 775/09, 3 December 2009; Oberverwaltungsgericht Nordrhein-Westfalen, 13 B 646/10, 2 July 2010; Oberverwaltungsgericht NordrheinWestfalen, 13 B 676/10, 13, July 2010. 
c) That contractual clauses exist that include territorial limitations accepted by economic operators. In this regard, geo-blocking does not require the establishment of state borders; in other words, parties can define other completely different territorial boundaries if they wish. For example, in Europe there are regional regulations that affect the European single market. ${ }^{15}$ However, these parties may include geo-blocking clauses in their contracts to comply with the obligations related to territorial limitations derived from law. For example, when a content provider owns copyright in some countries and licences that only include content for some of the countries in which they own those rights, the licence may require the licensee to "geo-block" users who want to connect from outside the countries for which the licence is issued. For example, if the TV channel Antena 3 obtains a licence from RAI to broadcast the series "Tuto puo succedere", it could limit the licence to Spanish territory with the result that Antena 3 would prevent users connecting from outside Spain to watch the programme on its website.

In conclusion, in general, nations expect both businesses and consumers to respect reasonable geo-blocking measures which purpose is to establish the territorial limits necessary for the proper functioning of the market. ${ }^{16}$ The example of a book distribution is illustrative: when a distributor obtains a licence to sell copies of a book in a country, the law requires the distributor to take reasonable steps to comply with the territorial limit of the licence. The distributor can check the address of the buyer in this regard before a copy of the book is sent. The law does not require the distributor to attach data in relation to transportation, to place a radio frequency identification tag in each copy or to install a surveillance system to control the movement of each copy to prevent them from leaving the country's territory. While the contract could theoretically force the publisher to use such measures, if incorporated into law, economic operators would consider all these measures to be excessive, which would discourage these

15 Regulation (EU) 2018/302 of the European Parliament and of the Council of 28 February 2018 on addressing unjustified geo-blocking and other forms of discrimination based on customers' nationality, place of residence or place of establishment within the internal market and amending Regulations (EC) No 2006/2004 and (EU) 2017/2394 and Directive 2009/22/EC (Text with EEA relevance.) Official Journal 60I, 2.3.2018, pp. 1-15.

16 P.A. de Miguel Asensio, Contratos Internacionales..., p. 45. 
types of extraterritorial operations. In short, the measures adopted must be reasonable and justifiable for both parties.

\subsection{Establishing globally accepted minimum standards}

Another acceptable solution to justify geo-blocking is one that considers the creation of minimum standards applied extraterritorially and accepted by the entire international community. ${ }^{17}$ The difficulty in this case is to establish minimum legal standards that are sufficiently precise and adapted to the technological needs of each moment that respect the socalled "principle of technological neutrality".

The principle of technological neutrality ${ }^{18}$ is a term that was coined by the 1996 UNCITRAL Model Law on Electronic Commerce by establishing that:

By incorporating into its domestic law the procedures prescribed by the Model Law for all cases in which the parties choose to employ electronic means of communication, a State will be creating a neutral legal environment for any technically viable means of commercial communication.

Subsequently, it was also incorporated into the preface of Framework Directive 21/2002/EC ${ }^{19}$, which regulates a common framework for electronic communications networks and services, and into the articles of

17 J.A. Muir, P.C. Van Oorschot, Internet Geolocation: Evasion and Counterevasion, ACM Computing Surveys 2009, vol. 42, no. 1, pp. 5-10.

18 The principle of technological neutrality has several meanings depending on the context in which it is used. The concept of technological neutrality is used to describe the position of the Public Administration in relation to its suppliers, especially suppliers of computer goods and services. Technological neutrality is also understood to mean the equality of providers vis-à-vis the Public Administration, or the position that the Public Administration must adopt vis-à-vis provider that, over time, has required a privileged position with respect to the Public Administration. To purchase essential products. From the user's point of view of the user, and especially in the field of electronic administration, technological neutrality implies that said user must be able to contact the Public Administration by any electronic system and in an easy and affordable way.

19 Directive 2002/21/EC of the European Parliament and of the Council of 7 March 2002 on a common regulatory framework for electronic communications networks and services, Official Journal L108, 24 April 2002, pp. 33-50. 
Directive 2009/140/EC ${ }^{20}$, which incorporated it as a basic principle of regulation of electronic communications.

The minimum standards must be based on this principle to avoid discriminatory effects in the application of the technologies employed and to favour the development of ICTs. For Cullel March ${ }^{21}$, the regulatory principle of technological neutrality must meet four criteria: discrimination, sustainability, efficiency and consumer safety:

a) Non-discrimination serves to ensure an egalitarian and permanent regulation that avoids changes in the legal framework depending on the technology used to provide the service. This prevents the application of different regulatory regimes depending on the technology applied.

b) Sustainability refers to technology evolving faster than regulation. Therefore, the regulations used must be sustainable and flexible to avoid periodic legal reviews in order to adapt it to constant technological developments or market conditions. In short, the rules do not have to be static but sufficiently flexible and dynamic to evolve in parallel with technological development without the need for continuous regulatory reviews.

c) Unlike sustainability, the effectiveness of regulatory norms not only requires adaptation to constant technological development but must also do so satisfactorily as structural changes occur in the market. ${ }^{22}$

d) Finally, the requirement of a technologically reliable regulation is related to the guarantee of certainty and safety for the consumer regardless of the technology used for the consumption of services or products.

In short, the principle of technological neutrality is linked to the obligation to provide a universal service that can be extended to all usable

20 Directive 2009/140/EC of the European Parliament and of the Council of 25 November 2009 amending Directives 2002/21/EC on a common regulatory framework for electronic communications networks and services, 2002/19/EC on access to, and interconnection of, electronic communications networks and associated facilities, and 2002/20/ EC on the authorisation of electronic communications networks and services. Official Journal L 337, 18 December 2009, pp. 37-69.

21 C. Cullel March, El principio de neutralidad tecnológica y de servicios en la UE: la liberalización del espectro radioeléctrico, Revista d' Internet, Dret i Política 2011, no. 11, p. 25.

22 I. Van der Haar, Technological Neutrality: What does it entail?, TILEC Discussion Paper 2007, no. 2007-009, pp. 13-15. 
technologies. In other words, universal service would be guaranteed regardless of the technology used. For example, in a licensing agreement between Sony and Netflix ${ }^{23}$, the parties agreed on a very general language according to which Netflix would use a standard geolocation service and language specifying that the geolocation service used should provide geographic location information based in DNS records, WHOIS databases and Internet subnet mapping, providing geolocation detection technology designed to detect IP addresses located in the territory used by registered users outside the territory. However, this solution has elements that ensure compliance with the controls generated by geo-blocking because users are allowed access to easily available tools to circumvent geo-blocking. ${ }^{24}$ For example, users use VPN, Chameleon, MyExpatNetwork, or more complicated tools, such as Tor, to bypass controls and access content on the Internet that would otherwise be inaccessible to them due to their location.

In this regard, nations are aware that there are users who jump across the borders and accept these digital leaks as part of the game. For example, countries recognize an exception to the intellectual property law for small amounts of materials protected by intellectual property rights that travellers carry in their luggage for personal use. In the same way, these leaks are allowed across national borders on the Internet, the question we ask ourselves being, what is the acceptable volume of leaks that states are willing to accept? The answer is generally given by national courts depending on the specific case raised..$^{25}$

23 M. Geist, Nobody's Perfect: Leaked Contract Reveals Sony Requires Netflix to Geo-Block But Acknowledges Technology is Imperfect, Michael Geist's blog, 17 April 2015, pp. 25-27.

24 D. Svantesson, B. Jerker, Geo-location technologies and other means of placing borders on the 'borderless' Internet, John Marshall Journal of Computer \& Information Law 2004, vol. 23, no.1, p. 115.

25 Spanski Enterprises, Inc. v. Telewizja Polska, S.A., D.D.C., 1:12-cv-00957-TSC, document 1, Complaint, 11 June 2012, p. 4. Jazette Enterprises Ltd. v. Commonwealth of Kentucky, Court of Appeals of Kentucky, 2014 WL 689044, 21 February 2014, p. 2. Aforementined inTrimble, M., Geoblocking, Technical Standards, in foodnotes 7 and 8. op. cit. pp. 56-57. Ass'nv. Brohl, 814 F.3d 1129 (10 Cir. 2016). Flo \& Eddie, Inc. v. Sirius XM Radio, Inc., 821 F.3d 265 (2d Cir. 2016). 


\subsection{Rules to prevent breach of geo-blocking}

Despite the desire to consider exceptional users' attempts to circumvent geo-blocking, the reality is that the manipulation and easy availability of VPNs, proxies and other tools to bypass geo-blocking is becoming increasingly widespread ${ }^{26}$, suggesting that continuous evasions can no longer be considered as an insignificant leak and leading both content providers and nations to increasingly include more provisions that prohibit Internet users from circumventing digital controls. For example, the German television station Sat.1 includes in its service clauses for the use of its online video portal a provision that prohibits users from "altering, evading or ignoring" the technical measures used by the station to limit territorially access to the content on their website. These measures range from termination of the contract to the filing of a lawsuit against the user for breach of the contract. ${ }^{27}$

However, in the absence of contractual provisions such as the aforementioned, countries currently do not have sufficiently coercive measures to sanction operators that do not respect geo-blocking except those that are covered by copyright rules or provisions on technological measures of protection or retransmission of audiovisual media. ${ }^{28}$

The question is whether nations should support this type of legislation that segments the market or whether they should instead seek spaces for regulatory harmonization to avoid the compartmentalization of international markets. Along this line, the so-called "dormant commerce clauses" used in the United States must be interpreted, since the federal government has the power and authority to regulate interstate commerce. Under these clauses, a state cannot enact a law that contradicts, interferes with

26 C. Ashraf, L.F. Alvarez León, The Logics and Territorialities of Geobloking, pp. 42-53, www.academia.edu/19262067/The_Logics_and_Territorialities_of_Geoblocking. These authors refer to four technical regulations that serve to apply geoblocking; 1 . Online Filtering: Proxy Filtering and TCP / IP Filtering. 2. TCP / IP filtering. 3. Denial of service. 4. Removal of content.

27 Terms of use for using the Sat video portal Sat.1, $\$ 4.1$ (g), http:/ / www.sat1.de/ service/nutzungsbedingungen/nutzungsbedingungen-fuer-die-nutzung-des-videoportals-von-sat-1 (accessed on 15.07.2018).

28 C. Hilliard, Evaluating the Legitimacy of Geo-Location Circumvention in the Context of Technical Protection Measures, Queen Mary Journal of Intellectual Property 2015, vol. 5, no. 2, pp. 166-167. 
or replaces a federal trade regulation. Its implementation is the result of the judicial opinions issued in several cases presented before the Supreme Court of Justice according to which a state cannot prevent the flow of interstate commerce by admitting restrictions or discriminatory rights on the goods that circulate between the states. ${ }^{29}$ Along this same line is the "digital single market" defended by the European Union. ${ }^{30}$

Regardless, the development of legislative and jurisprudential tools that attempt to circumvent geo-blocking should be used wisely, since these digital tools have on occasion been created with the aim of protecting privacy and personal data and guaranteeing freedom of expression and the right users have to access information.

However, courts have also ruled in this regard, understanding that a geo-blocking measure cannot be considered ineffective due to the fact that instructions are available to the user to access contents outside the authorized territory. This resolution was issued by the United States District Court of California, which rejected an argument that a measure cannot be considered effective if the tools to circumvent its application were "widely available on the Internet" ${ }^{31}$

\section{Legislation in the European Union: Regulation 2018/302 on geographic blocking}

The peculiarity that geo-blocking presents makes its regulation difficult because, as has been discussed, it is a conflictive tool in which there are numerous opposing interests that involve nations, economic operators

29 Flo \& Eddie, Inc. v. Sirius XM Radio, Inc., 821 F.3d 265 (2d Cir. 2016) sound recordings prior to 1972 and satellite radio. Ass'nv. Brohl, 814 F.3d 1129 (10th Cir. 2016), cert. Filed September 1, 2016 (state online sales tax).

30 G. Mazziotti, Is Geoblocking a Real Cause for Concern in Europe?, EUI Working Papers Law 2015, no. 43, esp. p. 18. M. Cardona, Geo-blocking in Cross-border e-Commerce in the EU Digital Single Market, Institute for Prospective Technological Studies Digital Economy Working Paper 2016/04, https://ec.europa.eu/jrc/sites/jrcsh/files/JRC101438.pdf (accessed on 5.05.2020).

31321 Studios v. Metro Goldwyn Mayer Studios, Inc., 307 F.Supp.2d 1085, 1095 (N.D.Ca. 2004). The court stated the argument is „equivalent to an argument saying that since master keys are easy to find on the black market, a lock is not effective door lock." 
and users. Hence, it has been the courts that have for the moment been responsible for establishing the limits in its application.

However, international organizations specializing in trade (WTO/ GATT) ${ }^{32}$ and regional organizations committed to free trade spaces (The European Union) are for now the entities responsible for its regulation.

Below we will analyse how the European Union has applied territorial and global mechanisms seeking a balance between the Free Market and the demands of the Member States protecting the rights of companies and consumers.

\subsection{Boosting the digital single market: Material, personal and territorial scope of the Regulation}

From the outset the European Union has opted for an open digital market that responded to the four freedoms present in its Constitutive Treaties. ${ }^{33}$ However, the protectionist measures present in the Member States in certain sectors (audiovisual, copyright, and online gaming, among others), have forced the community legislator to draw up Regulation 2018/302 (hereinafter: the Regulation) to regulate geo-blocking. ${ }^{34}$

32 Draft of the "Agreement on Trade in Services" that several countries negotiate within the World Trade Organization. See Draft Trade in Services Agreement (TiSA), Annex on Electronic Commerce, 16 September 2013 (WTO), https://www.bilaterals.org/IMG/ pdf/04.-annex-electronic-services.pdf (accessed on 3.05.2019). At the moment, 21 rounds have been held with no date scheduled for completion.

33 In May 2015, the European Commission criticized the use of geoblocking in the European Union in "A Unique Digital Market Strategy for Europe: Analysis and Evidence". A Digital Single Market Strategy for Europe - Analysis and Evidence, European Commission, SWD(2015) 100 final, 6 May 2015, p. 21-25. Also in Commission Decision of 6 May 2015 "Initiating an Inquiry into the E-commerce Sector Pursuant to Article 17 of Council Regulation (EC) No 1/2003" (file:///D:/Pen\%20dirve\%20malo\%20enero\%202016/ AEPDIRI/Lisboa\%20septiembre\%202018/Geobloking/ecommerce_decision_en.pdf) (retrieved on 13 May 2019).

34 P.A. de Miguel Asensio, El nuevo Reglamento de la Unión Europea sobre bloqueo geográfico y otras formas de discriminación, La Ley Unión Europea 2018, no. 59, pp. 6-8; A. López-Tarruella Martínez, El Reglamento 2018/302 sobre bloqueo geográfico injustificado y su relación con el criterio de las actividades dirigidas, Bitácora Millenium DiPr: Derecho Internacional Privado 2018, no. 7, pp. 58-60. 
Regulation 2018/302 arose lex specialis to clarify the generic norm that was once included in Directive 2006/123 $3^{35}$ in which situations were established that no differentiated treatment could be justified by reason of nationality, place of residence, or place of establishment. As stated by José Ignacio Paredes ${ }^{36}$, this rule is responsible for developing certain situations in which discrimination against clients based on nationality or residence criteria is specifically prohibited without there being an objective reason that justifies the difference in treatment. In this way, the Regulation respects the principle of technological neutrality claimed at the international level.

For this, Regulation 2018/302 distinguishes two types of discrimination that at no time may be applied in the European area. One is the direct discrimination that occurs when the sale of products or the provision of services leads to a different treatment of clients exclusively based on their nationality, residence or place of establishment. On the other hand, the market also gives rise to indirect discriminations that result in treating customers differently through substitute factors that are different from those that give rise to direct discrimination, producing equivalent discriminatory effects. For example, indirect discrimination would also occur which is also prohibited by the Regulation - if blocking is applied based on the IP address used to access an online interface, the address provided for the delivery of goods, the choice of language or Member State issuing the payment instrument to the customer.

In essence, Regulation 2018/302 penalizes the discrimination, direct or indirect, of certain recipients to whom the difference in treatment is applied when in similar situations without there being any objective justification for applying this differentiation. ${ }^{37}$

However, in order to determine the extent of discrimination, it will be necessary to follow the jurisprudence of the Court of Justice of the European Union (CJEU), which has ruled on discrimination in cases related

35 Directive 2006/123/EC of the European Parliament and of the Council of 12 December 2006 on services in the internal market Offical Journal J L 376, 27.12.2006, p. 36-68.

36 J.L. Paredes Pérez, Medidas contra el bloqueo geográfico injustificado: El Reglamento (UE) 2018/302 y su incidencia sobe las normas europeas de Derecho internacional privado, Revista Electrónica de Estudios Internacionales 2018, no. 35, p.5.

37 P. Garrone, La discrimination indirecte en droit communautaire: vers une théorie générale, Revue Trimestrelle de Drot Européen 1994, no. 3, pp. 425-426. 
to freedom to provide services and adjudged there cannot be any discrimination by reason of nationality ${ }^{38}$, but allow discrimination only on grounds of residence when its application can be justified objectively and proportionally.

With this argument, Regulation 2018/302 considers various unjustified forms of geo-blocking whereby retailers block Internet access to specific websites or redirect customers to other websites without their consent (Article 3). The Regulation aims to limit the blockade to support electronic commerce by creating a European digital single market. On the other hand, it considers those situations of discrimination of clients by means of application of the general conditions of access for which an exhaustive list has been drawn up that must be respected by economic operators according to the nationality, place of residence or place of establishment of the user (Article 4). Finally, it considers those discrimination cases that can arise for reasons related to payment (Article 5) and in the agreements that restrict competition in cases of passive sales (Article 6). It can be said that in this case the interest of the states prevails over the economic interest, thus breaking the principle of technological neutrality that establishes non-discrimination in the use of digitization.

The Regulation excludes from this prohibition non-economic general interest services, transport services, audiovisual services, gaming activities, retail financial services, health services, private security services, copyright and related rights. All of the above will be subject to their own specific regulation (Article 1-4, 1-5). Apart from these exceptions, which are justified below, it can be stated that its material scope of application generally covers services provided by non-audiovisual electronic means.

In order to promote commercial relations at a global level, Regulation 2018/302 is applied to any retailer that sells online in the EU, including not only companies domiciled in the EU but also those that are outside the community territory but operate within it.

In addition, Regulation 2018/302 defines geo-blocking practices aimed at consumers (Article 2.12) domiciled in the EU (an individual acting for purposes unrelated to their commercial, business or professional activity) as action against any customer, understanding thereby any company domiciled in the EU that attempts to acquire a product or service within

38 M. Gardeñes Santiago, La imperatividad internacional del principio comunitario de no discriminación por razón de la nacionalidad, Revista de Instituciones Europeas 1996, vol. 23, p. 868. 
the EU to be its final recipient. This extraterritorial extension will require a reinterpretation of the criteria of the directed activities included in EU regulations that deal with contractual obligations. ${ }^{39}$

Another feature included in the European geo-blocking regulation refers to its treatment for cross-border relations. In other words, its application to purely internal situations where all activities occur within a single state is excluded (Article 1-2), which could lead to cases of reverse discrimination, harming the consumer residing in a Member State where the service is offered.

However, Regulation 2018/302 also extends to retailers located in countries outside the EU but who orient their activities towards the European market. This Regulation seeks to ensure that all operators in the European area compete under the same conditions, resulting in this regulation being applied in the following cases:

a) When the retailer located in the EU or in a third country sells goods or provides services in a Member State other than that in which the customer lives or bases their establishment.

b) When the retailer located in the EU or a third country sells goods or provides services in the same Member State where the customer lives or bases their establishment.

c) When the retailer located in the EU or a third country sells or provides services in a Member State in which the customer finds him/ herself temporarily. ${ }^{40}$

\subsection{Limits to the digital single market: the barriers accepted in the application of Regulation 2018/302}

Although the geo-blocking regulation tries to preserve the digital single market, it has been necessary to create a series of barriers to protect a set of activities that are not currently liberalized in the various States, including the following.

39 A. López-Tarruella Martínez, El criterio de las actividades dirigidas como concepto autónomo de Dipr de la Unión Europea para la regulación de las actividades en Internet, Revista Española de Derecho Internacional 2017, vol. 69, no. 2, pp. 223-226.

40 J.L. Paredes Pérez, Medidas contra el bloqueo geográfico injustificado..., p. 25. 


\subsubsection{To prohibit an online seller for denying access to its website from another territory or redirecting the client to the website without their consent (Article 3)}

This prohibition prevents sellers from adapting websites depending on the countries to which they direct their commercial activity by redirecting it without the consent of the end user to the website of the place of their residence, based on the IP address. Unjustified discrimination occurs in this case when customers located in an EU Member State cannot access the same information that is being offered to customers who reside in other Member States.

This restriction can only be considered justified either when the client has given his or her consent for the redirection to occur, although in this case the client may always withdraw the consent at any time (Article 3.2), or when the blocking or limited access or redirection is established by legal means (Article 3.3). These cases are considered exceptional by the Regulation and therefore the retailer will be obliged to justify this situation in a clear and understandable way in the language of the online website that the customer had initially tried to access, thus complying with the principle of technological neutrality.

\subsubsection{Restrictions on access to products and services (Article 4)}

The restrictions referred to in Article 4 of Regulation 1218/302 refer to three situations in which access to products and services offered according to the general conditions of access is prohibited based on customer discrimination on the grounds of residence or place of the establishment of the client, understanding as such,

all conditions and other data, such as net sales prices that regulate the access of customers to the products or services offered for sale by a retailer established, applied and made available to the general public by the retailer or on their behalf and applied in the absence of an agreement individually negotiated between the retailer and the customer (Article 2.14).

Negotiated clauses established in an agreed manner between two or more retailers are therefore excluded.

The cases that are included under this restriction are:

- The sale of material goods.

In this case, the retailer will be obliged to provide the same conditions as to the customers resident in the Member State where the product is to 
be delivered or collected. However, it is specified in the Regulation that in this case the seller is not obliged to take the product to the Member State where the customer is located, which means the price of transport may affect the final price, with the price difference being justified in this case (recital 23).

- The provision of services electronically except for works protected by copyright or other protected provisions.

For this, Regulation 1218/302 justifies geo-blocking to protect electronic books, streamed music, games and software. This means that retailers will not be able to block these types of services electronically based on nationality, customer residence or establishment. The EU Regulation is referring in this case to cloud services, data storage services, website hosting, firewalls, search engines and Internet directories (recital 24).

- The services provided by the retailer of a Member State in another Member State in which the client resides.

Article 4.1 of the Regulation deals with services that are not offered electronically by providing the same solution, namely the prohibition of blocking, with the seller being obliged to offer the same general conditions of access without discriminating on the basis of nationality or the residence or establishment of the client. Specifically, the Regulation refers to hotel accommodation, sporting events, car hire, and musical festival tickets, among others (recital 25).

However, this non-discriminatory access obligation does not prevent traders from making offers or providing specific conditions of products or services in different Member States to certain customer groups. Similarly, they can create websites on specific lines for the various Member States provided that this differentiation is not justified only for reasons related to nationality, residence or establishment of the client (Article 4.2).

In this regard, a retailer could offer different prices on different Internet sites provided that the customer, who accesses from another Member State, can buy the product under the same conditions as a client resident in that State. ${ }^{41}$

The prohibition does not work either if there is a specific provision either of the EU or of the Member States that restricts the sale of products or the provision of services to customers located in certain territories (Article 4-5). Similarly, retailers will be obliged in all their commercial

41 Ibidem, p. 12. 
operations to comply with the national legal requirements related to the products and services of the Member State in which the customer resides or is established (for example, the product labelling or its safety regulations) or at least to inform the client about this (Article 4.3).

As can be seen, the legislative rules of the European Union are conditioned by the interests of companies and consumers who find it necessary to establish protection measures within the European area. In this sense, it is necessary to create a balance that does not force to retreat the economic freedoms acquired since the creation of the Single Market, especially those that refer to the freedom to provide services.

\subsubsection{Discrimination in the means of payment}

Article 5 of Regulation 1218/302 leaves retailers free to decide the means of payment they accept for payment of their products or services, although it obliges them not to apply different payment terms on the basis of the residence or establishment of the customer. Similarly, it prohibits the unjustified difference in treatment based on the place the payment account is located, the establishment of the payment service provider or the place of issuance of the payment instrument, all of them in operations located in the EU (recital 32).

However, the Regulation authorizes the retailer:

- To postpone delivery of the products or providing the services until the retailer has verified that the payment has been made correctly.

- To the imposition of surcharges for the use of payment instruments provided they do not exceed the costs borne by the retailer for their use.

As can be seen again, Regulation 1218/302 breaks with market unity, establishing discriminatory criteria also in the way payment is made for services performed by digital means, creating borders within the European area.

\subsubsection{Prohibitions arising from the application of competition law (Article 6)}

Regulation 2018/302 prohibits and declares null passive sales agreements that impose obligations on sellers in relation to access to online sites, access to products and services and payment methods (Article 3, 4 and 5). This prohibition respects the rules on competition law included in the Treaty on the Functioning of the European Union (TFEU), specifically Articles 101 and 102. Particularly, it refers to contractual restrictions that 
prevent, for example, a retailer from responding to requests from individual clients, without delivery and outside the territory assigned contractually for reasons of nationality, residence or place of establishment.

\subsection{Support measures for the digital single market}

Finally, and with the purpose of promoting e-commerce, the European Commission has adopted another series of measures aimed at:

- Improving cross-border parcel delivery services through a regulation to improve prices and reduce obstacles when contracting courier services between Member States. ${ }^{42}$

- Measures to protect consumers through regulations that aim to strengthen the powers of national consumer authorities so that they act in a more coordinated way to tackle practices that harm consumers in cross-border operations. Foremost in this regard is the regulation on consumer protection. ${ }^{43}$

- The creation of a guide for the application of the Directive on unfair commercial practices that will serve to provide guidelines for its application to electronic commerce. ${ }^{44}$

The Regulation is therefore a necessary act which final aim is to eliminate the restrictions established in its own text. Hence its Article 9 establishes a revision mechanism in which proposed changes in areas subject to blocking can be periodically incorporated. In this way, the European Union complies with the sustainability and efficiency that are within the principle of technological neutrality by allowing the adaptation of rules to changes in the Market. In this regard, we must consider the EU

42 Proposal of Regulation of the European Parliament and the Council on cross-border parcel delivery services [SWD(2016) 166 final] [SWD(2016) 167 final], https:/ / ec.europa.eu/transparency/regdoc/rep/1/2016/ES/1-2016-285-ES-F1-1.PDF (accessed on 20.06.2019).

43 Regulation (EU) 2017/2394 of the European Parliament and of the Council of 12 December 2017 on cooperation between national authorities responsible for the enforcement of consumer protection laws and repealing Regulation (EC) No 2006/2004 (Text with EEA relevance), Official Journal L 345, 27 December 2017, pp. 1-26.

44 Practical Guide on Unfair Commercial Practices, https://europa.eu/youreurope/ citizens/consumers/unfair-treatment/unfair-commercial-practices/index_es.htm (accesed on 8.06.2019). 
Directive on collective management of copyright and related rights and the granting of multi-territorial licences for musical works for online use in the internal market as a preliminary step. ${ }^{45}$

\section{Conclusion}

From the foregoing it can be concluded that geoblocking is becoming more and more widely imposed as a tool for the digital market control based on the geographical location of the users. Currently there are national borders in online operation, especially in those related to copyrights, audiovisual regulations or online gaming platforms, etc. At the moment it is not possible to indicate a single legal act that controls the digital market. This control is related to the predominance of geoeconomics over geopolitics in which economic interests are above global digitization.

Despite this, regional organizations such as the European Union and world organizations such as the World Trade Organization, which are committed to free trade, have ruled against geo-blocking, as they are of the opinion that this tool slows international trade relations. However, all official initiatives related to cross-border access on the Internet recognize that there are areas of the law (intellectual property and game law among others) in which there will continue to be legitimate grounds for imposing restrictions in the cross-border scope of flows of goods and services ${ }^{46} \mathrm{How}-$ ever, countries must unite to develop new business models that provide favourable legislative and regulatory environments that harmonize the territorial rights on which these controls act to improve the environment of companies seeking to provide liberalized cross-border online access.

From the private sector perspective, extraterritorial relations should be promoted through collaborative contracts that help strengthen the digital single market and mitigate some of the effects of geo-blocking.

45 Directive 2014/26/EU of the European Parliament and of the Council of 26 February 2014 on collective management of copyright and related rights and multi-territorial licensing of rights in musical works for online use in the internal market Text with EEA relevance Official Journal L 84, 20.3.2014, pp. 72-98.

46 Article 36 of the Treaty on the Functioning of the European Union. 
For example, the creation of a system of "digital passports" 47 is an option that would facilitate access to Internet sites for users travelling abroad, which would allow them to continue enjoying all their benefits without any type of restriction.

Despite all of the above, users continue to criticize it and create new tools to circumvent its effects. Therefore, a good part of the regulations should aim to avoid these infractions through the interpretation made by courts in each specific case or as has been set out through progressive removal of existing regulatory barriers.

The European Union, contrary to the measures taken by the States, has decided to create its own rules to regulate geoblocking. In this sense, Regulation 1218/302 complies with the Principles of technological neutrality by avoiding non-discrimination of users of digital services, and consumer safety regardless of the territory where they access the service. On the other hand, it respects sustainability and efficiency by creating non-static standards that can be adapted to changes in the market. However, there is still time to achieve a single digital space since states, on the one hand, continue to limit free movement of goods and freedom to provide services as well as unity in means of payment made digitally. On the other hand, national courts continue to agree with economics operators that block the activities of those who are not under their control for accessing services and goods without respecting territorial principles.

\section{Bibliography}

De Miguel Asensio P.A., Contratos Internacionales sobre Propiedad Industrial, Madrit 2000.

De Miguel Asensio P.A., Derecho privado de Internet, Madrit 2000.

De Miguel Asensio P.A., El nuevo Reglamento de la Unión Europea sobre bloqueo geográfico y otras formas de discriminación, La Ley Unión Europea 2018, no. 59.

Gardeñes Santiago M., La imperatividad internacional del principio comunitario de no discriminación por razón de la nacionalidad, Revista de Instituciones Europeas 1996, vol. 23.

${ }^{47}$ M. Trimble, The Future of Cybertravel: Legal. Implications of the Evasion of Geolocation, Fordham Intellectual Property, Media \& Entertainment Law Journal 2012, vol. 22, no. 3, p. 600. 
Garrone P., La discrimination indirecte en droit communautaire: vers une théorie générale, Revue Trimestrelle de Drot Européen 1994, no. 3.

Goldsmith J.L., Wu T., Who Controls the Internet? Illusions of A Borderless World, New York 2006.

Hilliard C., Evaluating the Legitimacy of Geo-Location Circumvention in the Context of Technical Protection Measures, Queen Mary Journal of Intellectual Property 2015, vol. 5, no. 2.

Introduction à la Géoéconomie, Ed. P. Lorot, Paris 1999.

López-Tarruella Martínez A., El criterio de las actividades dirigidas como concepto autónomo de Dipr de la Unión Europea para la regulación de las actividades en Internet, Revista Española de Derecho Internacional 2017, vol. 69, no. 2.

López-Tarruella Martínez A., El Reglamento 2018/302 sobre bloqueo geográfico injustificado y su relación con el criterio de las actividades dirigidas, Bitácora Millenium DiPr: Derecho Internacional Privado 2018, no. 7.

Luttwak E., From Geopolitics to Geoeconomics, The National Interest 1990, no. 20.

Marketa T., The Multiplicity of Copyright Laws on the Internet, Fordham Intellectual Property, Media \& Entertainment Law Journal 2015, vol. 25, no. 2.

Millán García R., Geolocalización: legislación y consecuencias de su uso, Actualidad Administrativa 2019, no. 4.

Muir J.A., Van Oorschot P.C., Internet Geolocation: Evasion and Counterevasion, ACM Computing Surveys 2009, vol. 42, no. 1.

Ohmae K., El fin del Estado-Nación. El ascenso de las Economías Regionales, Santiago de Chile 1997.

Paredes Pérez J.L., Medidas contra el bloqueo geográfico injustificado: El Reglamento (UE) 2018/302 y su incidencia sobe las normas europeas de Derecho internacional privado, Revista Electrónica de Estudios Internacionales 2018, no. 35.

Sparke M., From Geopolitics to Geoeconomics: Transnational State Effects in the Borderlands, Geopolitics 1998, vol. 3, no. 2.

Svantesson D., Jerker B., Geo-location technologies and other means of placing borders on the 'borderless' Internet, John Marshall Journal of Computer \& Information Law 2004, vol. 23, no. 1.

Trimble M., The Future of Cybertravel: Legal. Implications of the Evasion of Geolocation, Fordham Intellectual Property, Media \& Entertainment Law Journal 2012, vol. 22 , no. 3 .

Trimble M., Geoblocking, Technical Standards and the Law, Scholarly Works Paper 2016, no. 947. 


\section{Sum mary}

The world is facing a new geoeconomic order in which digital media has changed the rules of the game. Borders are fuzzy and both companies and consumers try to strike a balance between free market access and the restrictions that protected economic interests establish. Based on these parameters, the European Union is trying to restructure the single market by applying global solutions that nevertheless collide with the protection measures demanded by economic operators, blocking the provision of services and the free movement of goods through so-called geoblocking. This practice consists of blocking access to services and/or the offer of products depending on the geographical origin of the user/client, either by redirecting users to local websites or simply by restricting access to their product brochure. The fact that consumer associations and users of digital platforms have considered this blockade as a real attack on the digital single market has led the European Union to seek legislative solutions. That is why the European Commission has promoted Regulation 2018/302, which aims to prevent unjustified geographical blocking and other forms of discrimination based on the nationality, place of residence or place of establishment of clients in the internal market. The justification of these protective measures as well as their location in the global geoeconomic space are studied in this work.

Key words: Geo-economics, Internet, Geo-blocking, Geolocation, Electronic Commerce

\section{GRANICE CYFROWE W UNII EUROPEJSKIEJ}

\section{Streszczenie}

Świat mierzy się z nowym porządkiem geopolitycznym, w którym media cyfrowe zmieniły zasady gry. Granice są zacierane i zarówno przedsiębiorstwa, jak i konsumenci starają się znaleźć równowagę pomiędzy dostępem do wolnego rynku a ograniczeniami, które chronią ustalone interesy gospodarcze. Uwzględniając te aspekty, Unia Europejska podejmuje działania w celu restrukturyzacji rynku poprzez zastosowanie globalnych rozwiązań, które jednakowoż stoją w sprzeczności ze środkami ochrony wymaganymi przez podmioty gospodarcze, blokujące dostęp do usług i swobodny przepływ towarów za pomocą tzw. blokowania geograficznego (geoblocking). Praktyka ta polega na blokowaniu dostępu do usług i/lub innych towarów uzależnionych od geograficznego pochodzenia użytkownika/klienta bądź za pomocą przekierowywania użytkowników na lokalne strony internetowe lub poprzez ograniczenie dostępu do ich oferty. Fakt, że stowarzyszenia konsumenckie i użytkownicy platform cyfrowych uznali te 
działania za rzeczywisty atak na cyfrowy rynek wewnętrzny, skłonił organy Unii Europejskiej do podjęcia kroków legislacyjnych w tej sprawie. Z tego powodu Komisja Europejska zainicjowała przyjęcie rozporządzenia 2018/302, mającego na celu zwalczanie praktyk blokowania geograficznego oraz innych form dyskryminacji klientów ze względu na przynależność państwową, miejsce zamieszkania lub miejsce prowadzenia działalności na rynku wewnętrznym. Niniejsza praca prezentuje uzasadnienie podjętych środków zabezpieczających oraz ich usytuowanie w globalnej geoekonomii.

Słowa kluczowe: geoekonomia, Internet, blokowanie geograficzne (geoblocking), geolokalizacja, handel elektroniczny (e-commerce)

\section{ЦИФРОВЫЕ ГРАНИЦЫ В ЕВРОПЕЙСКОМ СОЮЗЕ}

\section{Резюме}

Мир столкнулся с новым геополитическим порядком, в котором цифровые медиа изменили правила игры. Границы размыты, и как предприятия, так и потребители пытаются найти баланс между свободным доступом на рынок и ограничениями, защищающими устоявшиеся экономические интересы. Принимая во внимание эти аспекты, Европейский Союз принимает меры по реструктуризации рынка, применяя глобальные решения, которые, однако, противоречат мерам защиты, требуемым хозяйствующими субъектами, блокируя доступ к услугам и свободное перемещение товаров посредством так называемой геоблокировки (geoblocking). Эта практика заключается в блокировании доступа к услугам и / или другим товарам в зависимости от географического происхождения пользователя / клиента либо путем перенаправления пользователей на местные веб-сайты, либо путем ограничения доступа к их предложениям. Тот факт, что ассоциации потребителей и пользователи цифровых платформ сочли эти действия настоящей атакой на внутренний цифровой рынок, побудил органы Европейского Союза принять законодательные меры в этом вопросе. По этой причине Европейская комиссия инициировала принятие Постановления 2018/302, направленного на борьбу с практикой геоблокировки и другими формами дискриминации в отношении клиентов на основе национальности, места жительства или места ведения бизнеса на внутреннем рынке. В данной статье представлено обоснование принятых мер и их положение в глобальной геоэкономике.

Ключевые слова: геоэкономика, Интернет, геоблокировка (geoblocking), геолокация, электронная торговля (е-commerce) 
